\title{
The Impacts of Economic Development on Public Libraries: A Study Case of Bibliotheca Alexandrina Library
}

\author{
Samaa Soliman, Pan Wei \\ China Agricultural University Library, Beijing, China \\ Email: Msoliman.Waleed@gmail.com
}

Received 17 April 2016; accepted 15 May 2016; published 18 May 2016

Copyright (C) 2016 by authors and Scientific Research Publishing Inc.

This work is licensed under the Creative Commons Attribution International License (CC BY). http://creativecommons.org/licenses/by/4.0/

c) (i) Open Access

\begin{abstract}
Public libraries have the mandate of promoting the knowledge enhancement and awareness building of local residents. The national and local economic development on the other hand could directly impact the governmental public investment to the libraries and therefore affects their ability to deliver sufficient services either directly or indirectly. To investigate this sort of impact, the research extracted data from the annual reports of Bibliotheca Alexandria about various library services, collections, and financial data. As for the data concerning the Egyptian economy, it has been extracted mainly from World Bank data. Using Pearson product-moment correlation coefficient, results prove the existence of a strong relation between the country GDP and the allocated budget to the public libraries. Moreover, results show that there is a strong positive relation between the allocated budget to the libraries on one hand and the salaries $\&$ wages on the other hand, which explains how library staff and librarians are very likely to be affected by any budget reallocation, which is in turn affected by the economy development.
\end{abstract}

\section{Keywords}

Public Library, Bibliotheca Alexandria, Economic Development, GDP

\section{Introduction}

The Public Library is the local center of information, making all kinds of knowledge and information readily available to its users. Besides, it considered the local gateway to knowledge, and provided a basic condition for lifelong learning, independent decision-making and cultural development of the individual and social groups. As the Public Library shall in principle be free of charge. The public library is the responsibility of local and na- 
tional authorities. It must be supported by specific legislation and financed by national and local governments [1]. Therefore, public libraries in most cases are affected directly by any decisions made by local and national authorities concerning its budget. And these decisions obviously related to both local and nation-wide economy development.

This research is focused on empirical evidence to clarify the impact of economic development on the public libraries, where it is trying to measure these impacts using quantitative analysis based on historical data from Bibliotheca Alexandrina Library.

Researchers have long been concerned with the relation between economic development and public libraries, while a lot of studies were conducted to examine the role of public libraries in economic development; only a few studies investigated the impacts of economic development on public libraries.

As an example for the first group, a research has been conducted on Northport-East Northport Public Library, which estimates the economic impact of the operating and capital expenditures made by the library. And one of the key findings was that the library's operating and capital expenditures resulted in increased output, earnings and employment throughout Long Island but particularly in its local community [2]. Another study was conducted to measure the economic benefits of Indiana's public libraries, which found that Libraries are a good value. The direct economic benefits that communities receive from libraries are significantly greater than the cost to operate the libraries [3]. The Institute for Public Policy and Business Research undertook a study to determine how Kansas public libraries could play a more active role in supporting business and economic development in their communities. The major findings show that those libraries play an important role in providing materials and services to the business community [4]. Another study aimed to measure the value of Norwegian public library benefits to the population in monetary terms, which conclude that the Norwegian public libraries are worth four times more than they cost [5]. A study discussed the public library's role in society as a focal point for local economic development, which promotes the idea of setting up an information service in public libraries to provide added value information; which will be of great importance in justifying the existence of the public library within its surroundings [6]. Similar results showed that Toronto Public Library delivers a strong return on investment, through the delivery of library services, as it showed that for every dollar invested in Toronto Public Library (TPL), Torontonians receive \$5.63 [7]. Trying to determine economic benefit of public libraries for South Carolinians and to what extent they feel the public library contributes to their overall economic wellbeing. Results showed that the total direct economic impact of SC public libraries is estimated at \$222 million, while the actual cost of these services to the state and local governments is only $\$ 77.5$ million. This means that for every $\$ 1$ spent by state and local governments on SC public libraries the return on investment is $\$ 2.86$ [8].

From even boarder prospective, another study found that the return on investment in public libraries not only benefits individuals, but also strengthens community capacity to address urgent issues related to economic development. Public libraries are increasingly finding their "fit" in the formal and informal network of agencies, corporations, nonprofits, and community organizations working together to elevate levels of education and economic potential, making cities stronger [9]. Lastly, a study was conducted on selected Colorado Public Libraries in May 2006. Using a multiple case study approach, it is found that for most of the libraries participating in the study, the Return on Investment (ROI) was approximately five to one-that is, for every $\$ 1.00$ spent on public libraries, $\$ 5.00$ of value was realized by taxpayers [10].

On the other hand, as an example for the second group, other studies and reports investigated the impact of economic development on public libraries. The virtual entirety of public libraries in the US and UK were then, and still being, dependent on local or central public finance. These major sources of revenue were constrained as a result of these political and economic changes because the reduction of public spending was one of the major goals advocated [11]. The public library has no major source of income other than local tax revenue. Income from gifts and endowments was only 4.3 percent of the total in 1956 [12]. Other research tried to point out the importance of learning from the past as Libraries should take action and be proactive in the response to the challenges, that lay before them, they should publicize the importance of the work libraries do and the services they provide, and finally libraries should cooperate with other agencies who are providing other social and government services [13]. Another study emphasized the role of public libraries and how this role has significantly increased and libraries have greatly contributed to the improvement of information society, giving that there is a strong statistically significant linear correlation between the percentage of Internet users and the natural logarithm of GDP, which confirms, that the usage of ICT is one of the main drivers of change within society and 
economic development [14]. A research focusing primarily on acquisitions claimed that the libraries' main funding source is the national government; thus, their fortunes are tied to the broader economy. Libraries are especially concerned about paying for electronic resources, given their importance and high cost [15]. Another study suggests that in response to recent public library funding deficiencies, many people both inside and outside the field of librarianship have suggested that public libraries need to rely less on traditional government funding and more on alternative funding sources [16].

\section{Data Sources \& Methodology}

The data has been used in this research is based on a secondary data collected from various BA annual reports, mainly from 2003 until 2012, as for the data concerning the Egyptian economy, it has been extracted mainly from world bank data. Then, a data descriptive analysis is implemented to summarize the data.

To answer the research question about the impact of economic development on the BA library, a Pearson product-moment correlation coefficient is evaluated on two steps; in the first step, the relationship between the GDP (PPP)—as one important economic development indicator, and BA allocated budget is investigated.

$$
r=\frac{n\left(\sum \mathrm{GDP} * B\right)-\left(\sum \mathrm{GDP}\right)\left(\sum B\right)}{\sqrt{\left[n \sum \mathrm{GDP}^{2}-\left(\sum \mathrm{GDP}\right)^{2}\right]+\left[n \sum B^{2}-\left(\sum B\right)^{2}\right]}} \cdots \text { where } B \text { is the Allocated Budget. }
$$

Then in the second step, various library indicators are tested against the allocated budget such as the different library collection categories, membership, visitors, salaries \& wages, and the general expenses as Figure 1 illustrates.

\section{GDP Growth and the Library Investment Increase}

The Egyptian economy is one of the Middle East's most versatile economies, which the sectors of agriculture, industry, tourism and services engaged in comparable proportions in its basic configuration. The average number of the work force in Egypt is about 26 million, according to 2010 estimates. They are distributed on the service sector (51\%), agriculture sector (32\%) and the industrial sector (17\%). The Egyptian economy depends basically on agriculture, Suez Canal revenues, tourism, taxation, cultural and media production, petroleum exports and remittances of more than three million Egyptians abroad, mostly in the Gulf States, the United States, Europe and Australia [17].

Egypt has one of the most developed and diversified economies in the Middle East. Until 2010, Egyptian economy was growing an average 5 percent a quarter as a result of several economic reforms attracting foreign investments. During that time, the economy and the living standards for majority of population improved. Yet, living conditions for the average Egyptian still remained poor and large income disparities continued to grow,

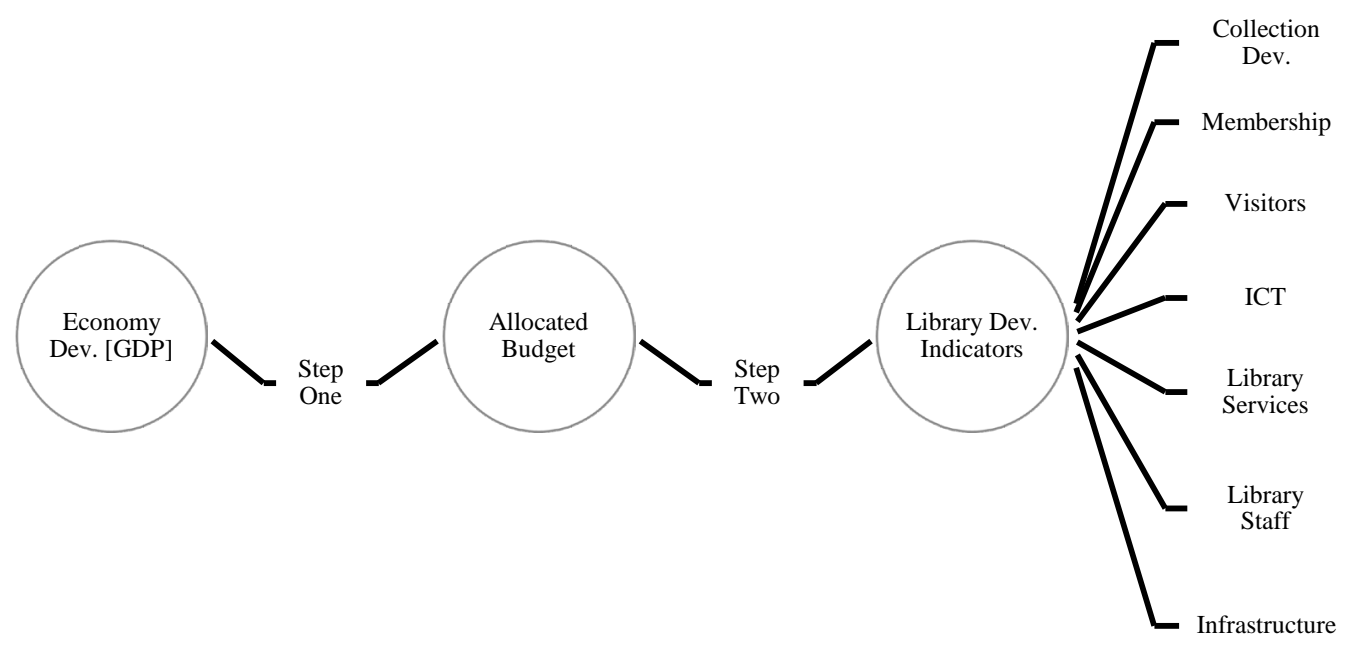

Figure 1. Analysis methodology. 
leading to the public discontent. In the wake of the January 25th Revolution, the country exerted strenuous efforts to restore the economy on right track and overcome the obstacles through rallying the efforts internally and openness to the world to act dynamically in the world's economy and finance. And also as it brought down President Hosni Mubarak regime, have caused economic slowdown as political and institutional uncertainty and rising insecurity continue to hurt tourism, manufacturing, and construction [18].

One important indicator which is the GDP PPP, which shows in general increase in the country GDP from $\$ 565$ billion in 2003 to reach about \$862 Billion in 2012 as Figure 2 shows [19].

On the other hand, the Egyptian public library movement, which had already acquired momentum before 1952, benefited from Nasser's support for mass education during the first decade of the Egyptian revolution. The perception that education fosters national development induced the new regime to take deliberate actions in support of the library movement in Egypt, in the early stages of the revolution. School libraries were given special attention as part of the government's overall interest in mass education, which the intention of making school libraries "an integral part of school education". Government and special libraries were also among the Nasser regime's highest priorities. Convinced of the need for scientific information in research, teaching and industry, the new regime established new science and research libraries. The Egyptian public library movement, especially the Egyptian National Library "Dar al-Kutub" (House of Books), benefited directly from Nasser's early affirmation of education as a birthright of every Egyptian. Annual book acquisitions almost tripled between 1952/53 and 1961/62. The spread of education and culture was also associated with a significant increase in Egyptian book production, and the Copyright-Legal Deposit Law enacted by Nasser's regime in 1954 guaranteed Dar al-Kutub and its branch public libraries a constant acquisition of national publications. Moreover, a total of sixty popular culture libraries were established in rural Egypt between 1958 and 1970. Then, the number of public libraries, library users, book acquisitions, and national library budgets continued to expand—with not the same speed as before -during the Sadat era (1970-1981) [20] and Mubarak era as well (1982-2011).

Libraries are located throughout Egypt, including remote regions in Upper Egypt and Sinai. As expected, most of the libraries are located in greater Cairo and Alexandria. Nasser's dream of a library in every village, regardless of size, has not been achieved. It can be seen that the per capita number of libraries in Egypt is uneven with respect to county or governorate. The governorate with the lowest number of people/library is Suez (3,440 people per library) and the lowest village is Sohag (118,149 people per library). A number of governorates—all in Upper Egypt—stand out with the fewest libraries per capita. They are Beni Sweif, Qena, Behaira and Sohag as Table 1 shows.

The average per capita library figure in the United States is approximately 17,000. This means that there are about twice as many libraries per capita in the US compared to Egypt.

The rate of new library construction lags population growth in Egypt. The projected population growth in Egypt in $1.61 \%$ [19] compared with new construction for libraries at less than $0.90 \%$. The rate of new library

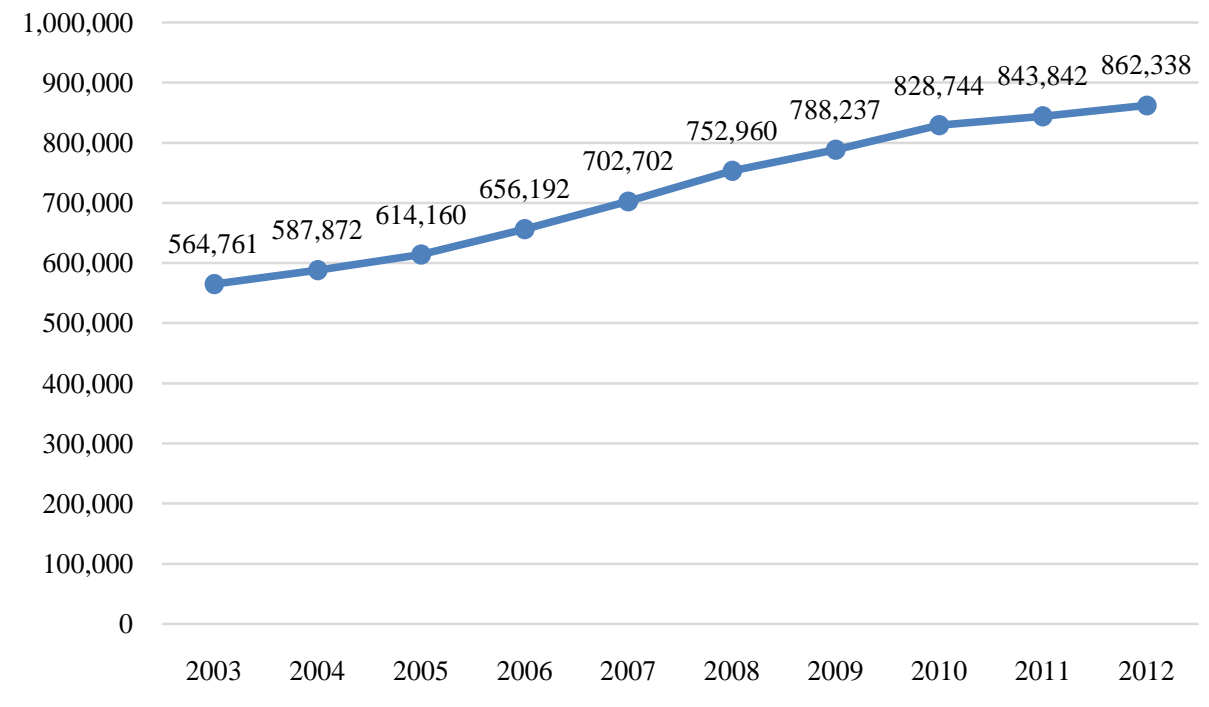

Figure 2. Egypt GDP PPP (constant 2011 international \$), billion. Source: [19]. 
Table 1. Libraries per capita in Egypt.

\begin{tabular}{|c|c|c|c|c|}
\hline Governorates & Total population & Poverty rate & No of libraries & Persons/library \\
\hline Al Wadi Al Gaded & 169,896 & 6.24 & 42 & 4045 \\
\hline Alexandria & $4,087,682$ & 6.41 & 73 & 55,996 \\
\hline Assuit & $2,953,561$ & 60.97 & 124 & 23,819 \\
\hline Aswan & $1,187,943$ & 40.92 & 33 & 35,998 \\
\hline Beni Sweif & $2,253,076$ & 41.45 & 26 & 86,657 \\
\hline Behaira & 4,676,382 & 23.51 & 78 & 59,954 \\
\hline Cairo & $7,774,143$ & 7.62 & 308 & 25,241 \\
\hline Dakahleya & $4,830,513$ & 9.30 & 256 & 18,869 \\
\hline Domiat & $1,074,948$ & 1.11 & 64 & 16,796 \\
\hline Fayoum & $2,441,333$ & 28.71 & 44 & 55,485 \\
\hline Gharbya & $3,940,061$ & 7.64 & 59 & 66,781 \\
\hline Giza & 6,562,923 & 22.97 & 176 & 37,289 \\
\hline Ismailia & 832,315 & 18.84 & 41 & 20,300 \\
\hline Kafr Al Shikh & $2,576,792$ & 11.20 & 43 & 59,925 \\
\hline Luxor & 440,110 & 18.44 & 10 & 44,011 \\
\hline Marsa Matrouh & 212,219 & 4.32 & 8 & 26,527 \\
\hline Menia & $2,895,597$ & 30.93 & 36 & 80,433 \\
\hline Menofia & $3,941,818$ & 17.93 & 56 & 70,390 \\
\hline North Sinai & 300,502 & 27.87 & 22 & 13,659 \\
\hline Port Said & 384,571 & 4.43 & 40 & 9614 \\
\hline Qalyoubya & 4,175,659 & 11.33 & 111 & 37,619 \\
\hline Qena & 2,938,079 & 39.02 & 32 & 91,815 \\
\hline Red Sea & 225,937 & 4.00 & 10 & 22,594 \\
\hline Sharkeya & $5,307,846$ & 19.15 & 71 & 74,758 \\
\hline Sohag & 3,662,619 & 47.54 & 31 & 118,149 \\
\hline South Sinai & 116,379 & 0.00 & 10 & 11,638 \\
\hline Suez & 103,478 & 1.94 & 30 & 3449 \\
\hline Total & $70,066,382$ & 21.56 & 1834 & 38,204 \\
\hline
\end{tabular}

construction should be increased, especially in places such as the Fayoum that have not had a new library in built in nearly 10 years and have a rapidly growing population as Figure 3 shows.

A large number of private or semi-private libraries exist at universities, schools, social, sport and military clubs and in mobile libraries. These collections should be considered when thinking of the overall access to libraries in Egypt [21].

However, in general the number of public libraries in Egypt fluctuated over time, as it reached its minimum value in 2003 with only 112 thousand visitors, and reached its maximum value in 2013 with 602 thousand visitors [22] as Figure 4 illustrates. 


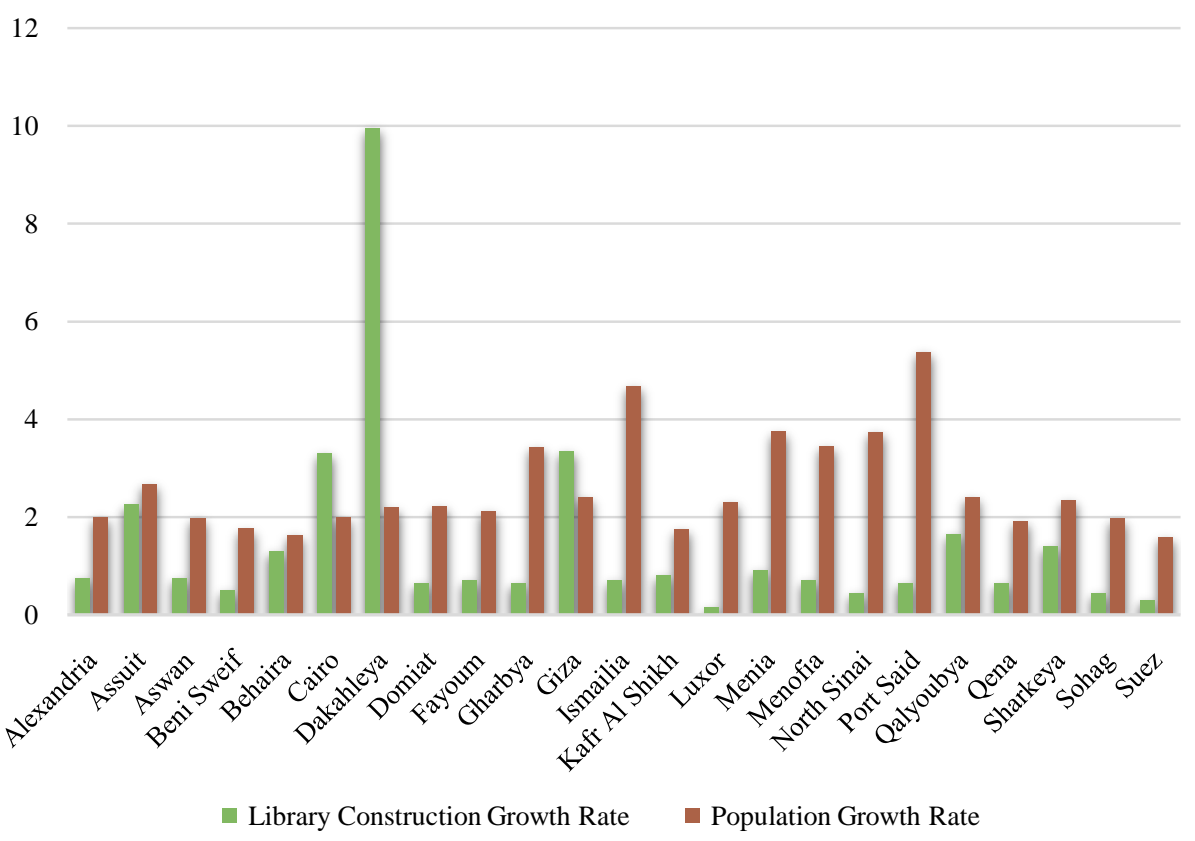

Figure 3. Population growth rate and library construction growth rate in different Egyptian governorates.

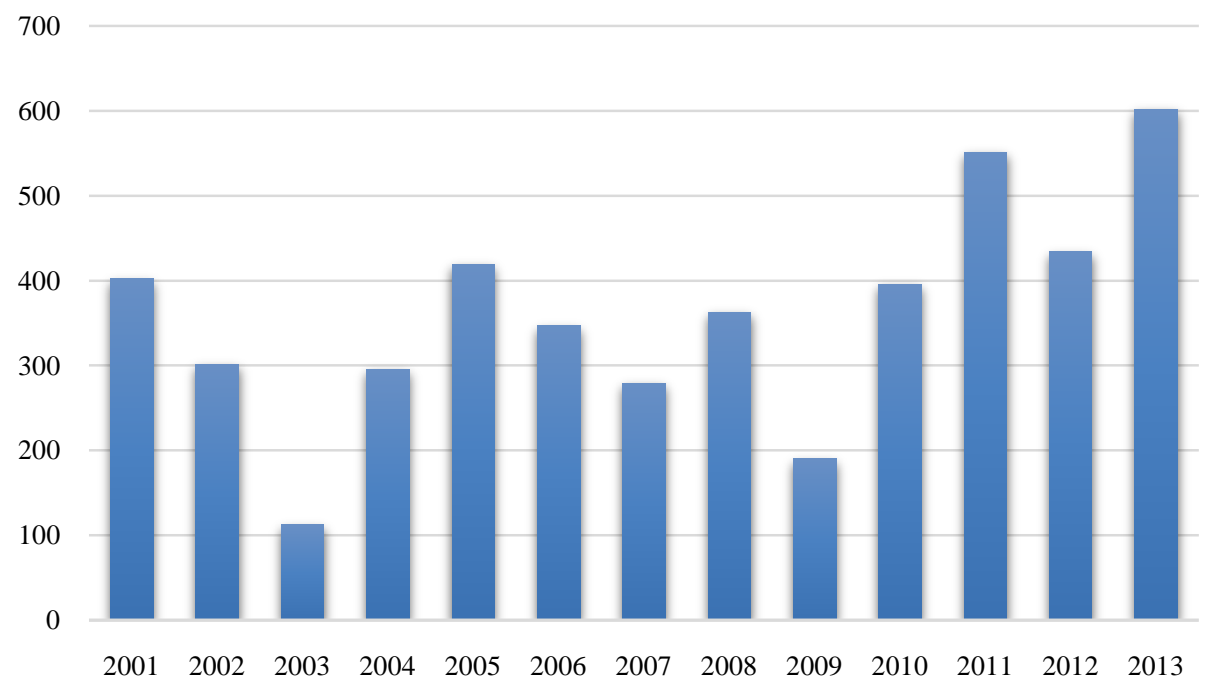

Figure 4. Number of libraries visitors in thousands. Source: [22].

\section{The Case Study of Bibliotheca Alexandrina}

The idea of reviving the ancient library of Alexandria had been floating around since 1974, when a committee set up by the Alexandria University selected a plot of land for its new library, between the campus and the seafront, close to where the ancient library once stood. The notion of recreating the ancient library was soon enthusiastically adopted by other individuals and agencies throughout Egypt. The United Nations Educational, Scientific, and Cultural Organization (UNESCO) was quick to embrace the idea of endowing the Mediterranean region with a center of cultural and scientific excellence, and the project was well underway by the late 1980s. In 1990 a conference was held in Aswan to help the government figure out the logistics of funding such as costly project. 65 million dollars was pledged b various agencies, mainly from the gulf Arab states. Construction on the library's complex began in 1995 by Snøhetta, a Norwegian architectural firm. After two-hundred and twenty million dollars in total was spent, the Bibliotheca Alexandria officially opened on $16^{\text {th }}$, 2002 [23]. 
The library has shelf space for eight million books, with the main reading room covering 20,000 square meters on eleven cascading levels as displayed in Figure 5. The complex also houses a conference center; specialized libraries for maps, multimedia, the blind and visually impaired, young people, and for children; four museums; four art galleries for temporary exhibitions; 15 permanent exhibitions; a planetarium; and a manuscript restoration laboratory. The library's architecture is equally striking. The main reading room stands beneath a 32-meter-high glass-paneled roof, tilted out toward the sea like a sundial, and measuring some $160 \mathrm{~m}$ in diameter. The walls are of gray Aswan granite, carved with characters from 120 different human scripts [24].

\subsection{Allocation of Budget and Donations}

Bibliotheca Alexandrina have its own independent budget, and its financial year starts and end with the financial year of the government's budget. And the Library have a separate account in the Central Bank of Egypt as well. In general, the library has the following resources of funding:

- The allocations provided for it by the state.

- The support, gifts, donations, bequests, and financial contributions from internal or external sources.

- The income that it receives for its services and the returns on the invested funds in its projects.

- Any other sources that may be legally allocated to the Library [25].

Since Aswan meeting, the library receives a lot of donations and contributions from many countries, international agencies and companies such as: United States Agency for International Development (USAID), Qatar Emirate, European Commission (EC), World Bank, UNESCO, Islamic Development Bank (IDB), and others.

Table 2 shows how the allocation of budget changes over time-which mainly represents grants from the ministry of finance against wages and salaries, and current expenses. As the government increases the budget allocated to the library from around 17 million EGP in 2003 which represents only about $31 \%$ from the total revenues, to reach about 125 million EGP in 2012, which represents around $75 \%$ of the total revenues. On the other hand, the other sources of revenues such as donations and the library own investment revenue and projects, which was represents about $69 \%$ of total revenues decreased to become $25 \%$ only of the total revenues. As an average, the government allocated budget represents around 83 million EGP of the library revenues comparing to about 40 million EGP of revenues from donations \& projects as Figure 6 shows.

As for the expenses, there are two main categories of it, one is salaries \& wages, which was around 20 million EGP in 2003 and reached about 108 million EGP in 2012. The other category is the general and administrative expenses, that represents all operation costs such as conference expenses, utilities, exhibitions, taxes, travel, etc. which increased from 29 million EGP in 2003 to reach about 48 million EGP in 2012. Other category of expenses represents provisions providing for employees' end-of-service benefits, contingent liabilities and allowance for bad debt.

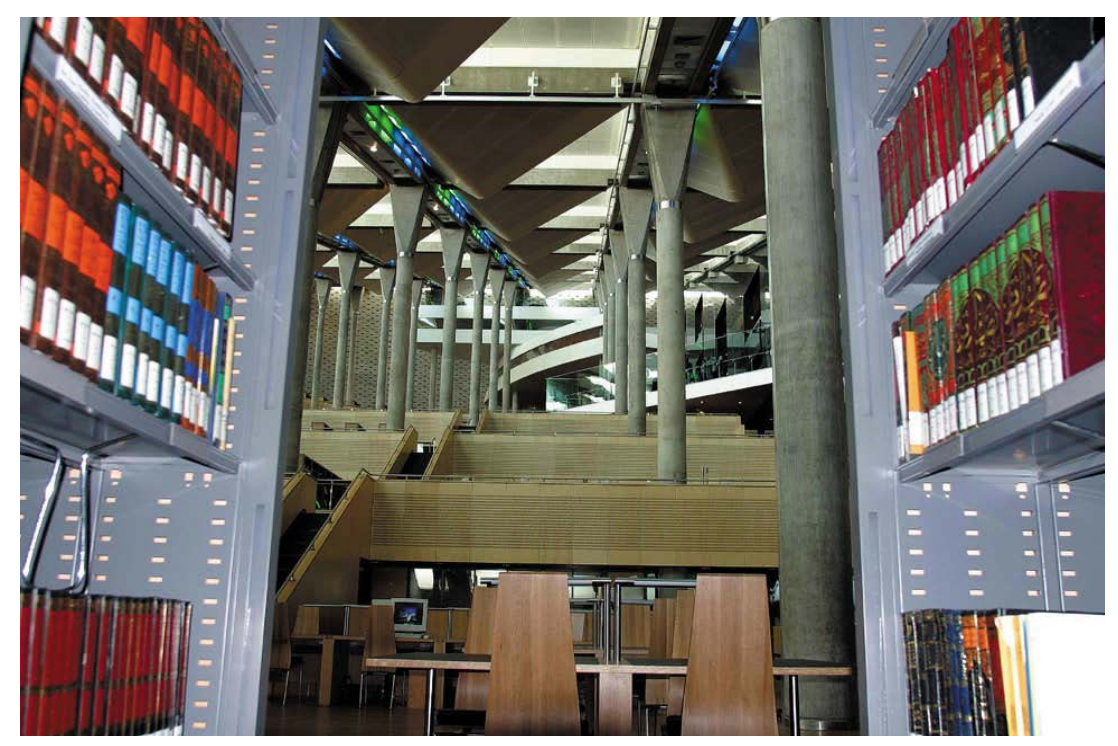

Figure 5. Interior view of the library. 
Table 2. Revenues \& expenses of BA-million EGP.

\begin{tabular}{|c|c|c|c|c|c|c|c|c|c|c|c|c|}
\hline \multirow{2}{*}{ Year } & \multicolumn{5}{|c|}{ Revenues } & \multicolumn{7}{|c|}{ Expenses } \\
\hline & $\begin{array}{l}\text { Gov. } \\
\text { grants }\end{array}$ & $\%$ & $\begin{array}{l}\text { Donation } \\
\text { \& projects }\end{array}$ & $\%$ & Total & $\begin{array}{l}\text { Salaries } \\
\text { \& wages }\end{array}$ & $\%$ & $\begin{array}{c}\text { General } \\
\text { expenses }\end{array}$ & $\%$ & Other ${ }^{*}$ & $\%$ & Total \\
\hline 2003 & 17.21 & 31.01 & 38.29 & 68.99 & 55.50 & 19.81 & 24.54 & 29.06 & 36.00 & 31.85 & 39.46 & 80.72 \\
\hline 2005 & 59.55 & 70.72 & 24.65 & 29.28 & 84.20 & 34.21 & 42.53 & 45.23 & 56.23 & 1.00 & 1.24 & 80.44 \\
\hline 2006 & 55.46 & 62.74 & 32.93 & 37.26 & 88.39 & 38.10 & 44.34 & 47.83 & 55.66 & 0.00 & 0.00 & 85.93 \\
\hline 2007 & 80.64 & 73.37 & 29.26 & 26.63 & 109.90 & 50.99 & 48.08 & 53.06 & 50.03 & 2.00 & 1.89 & 106.06 \\
\hline 2008 & 76.97 & 63.10 & 45.01 & 36.90 & 121.99 & 61.20 & 49.19 & 61.73 & 49.61 & 1.50 & 1.21 & 124.44 \\
\hline 2009 & 95.03 & 67.98 & 44.77 & 32.02 & 139.80 & 74.35 & 54.80 & 58.82 & 43.35 & 2.50 & 1.84 & 135.66 \\
\hline 2010 & 110.95 & 66.96 & 54.75 & 33.04 & 165.70 & 90.42 & 56.27 & 66.76 & 41.55 & 3.50 & 2.18 & 160.67 \\
\hline 2011 & 129.18 & 73.24 & 47.21 & 26.76 & 176.39 & 113.09 & 64.73 & 57.95 & 33.17 & 3.66 & 2.09 & 174.71 \\
\hline 2012 & 124.89 & 75.18 & 41.23 & 24.82 & 166.11 & 108.33 & 66.09 & 48.39 & 29.52 & 7.21 & 4.40 & 163.93 \\
\hline
\end{tabular}

Other ${ }^{*}$ includes Provisions \& Depreciation for the first year. Source: [26].

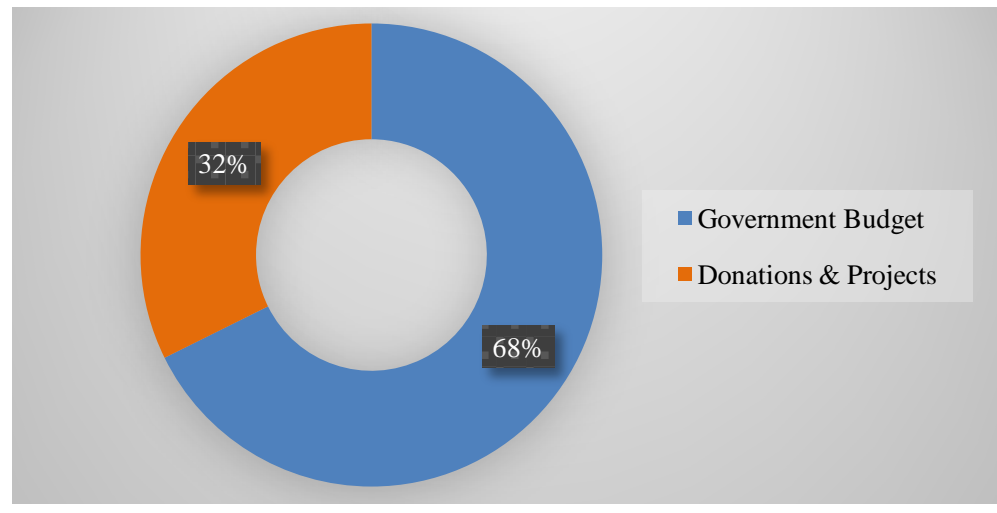

Figure 6. Source of revenues of BA. Source: [26].

In 2012, the government underfunded the salaries budget below the level of actual expenditure of the financial year 2011. So, to confront the situation, the management tightened spending, refused to replace outgoing staff, allowing attrition to reduce the wage bill, along with a general tightening of expenditures. But the reduction in activities also meant a reduction in revenues. The budget, which was successfully balanced at the end of the year but did not allow for any salary increases to anyone, not even to cover inflation. The team of BA also arranged for a cut of $10 \%$ in the top salaries which enabled the management to give the lower salary levels $5 \%$ increases, within the same frozen, underfunded envelope [27].

\subsection{Library Components}

The Library of Alexandria complex includes: The Main Library, the Taha Hussein Library for the visually impaired, the Young People Library, the Children Library, Multimedia Library, Antiquities Museum, Manuscript Museum, Science Museum, Planetarium, International School of Information Studies (ISIS), Calligraphy and Script Institute, Conservation and Restoration Laboratory, Center Documentation and Research, Conference Center, ancillary services, multipurpose rooms and exhibition areas.

\subsection{Electronic Resources}

The Information and Communication Technology (ICT) infrastructure is arguably the best in Egypt: Fiber Optic backbone and Gigabit Ethernet technology throughout our buildings with 155 Mbps Internet connectivity; with 
over 360 public workstations and 940 for the staff, with over 60 servers. Most of the standard functions have been computerized: Library Information System, integrated digital library services, intranet, Enterprise Resource Planning and access control and ticketing systems [28]. The library is also offering a selection of databases and websites to serve all users and researchers in most areas of specialization with e-books and full text online for periodicals or other research tools. Internet Archive contributed through the generosity of Brewster Kahle, its founder and CEO, is a backup copy of material available on the Internet from 1996 to the present, much of which is no longer on the Internet. It contains over 100 terabytes of data (which is equivalent to about 10 billion pages, 2000 hours of video news films and 1000 documentary films. The material from the Internet represents snapshots at different times of the topics from over 16 million sites representing the voices of millions of authors and web initiators over the last six years.

\subsection{Library Services}

Reception \& Visitors Services: to guide new comers and explain to visitors the historical background. It also, gives tours to explain the services and activities of the Library and other sections of the cultural complex.

Information Services: Open Access Shelves display the library's collections through a reading area, which cascades over the 7 levels of the library, and accommodates 2000 readers at the same time.

The Bibliotheca Alexandrina is thought to have the largest reading room of all the major libraries of the world. It also serves researchers with 200 study rooms spread over the 7 levels of the library. Each information desk is designed to serve the public and acquaint the user or researcher with OPAC, electronic resources, the multimedia and collections and other facilities.

General Information Services: The General Information Services desk is located at the Entrance of the Main Library. It gives general information to the public and refer users to the appropriate specialized information desk.

Orientation Services: Orientation programs are scheduled to facilitate the use of the library to all its users, acquaint them with all the services offered and the use of the electronic catalog of the library referred to by the OPAC or the on-line public access catalog, the use of electronic resources, multimedia resources.

Specialized Tours: will be scheduled for professionals and librarians to learn the different systems the library is implementing as well as other related matters, which might interest them; like Work Procedure; Human Resources Development programs; Collection Development Policy.

Membership Services: Your membership card gives you the benefit of using the library and all its facilities. You can borrow books, use reading areas, and reserve study rooms, if you qualify. The Membership Card can also allow you reduced rates to enter Museums, Exhibits and other Cultural Performances.

Specialized Information Services: There are ten specialized information desks designed to serve users and researchers. Other than the three libraries for the Young People, Children, and the Blind or visually impaired.

Researchers Information Services: Each level is designed to serve the generate reader with a collection of material if a certain subject or subjects displayed in the open shelve. Researchers may also reserve study rooms to work in an environment surrounded by books \& printed reference sources, with access to selected databases and other electronic resources.

Other Services: Photocopying: users and researchers can purchase pre-paid cards at the General Information Desk to do their own photocopying in the dedicated areas on level B2 and B4. Users \& researchers are kindly requested to follow instructed copyright rules and regulations. Printing: users and researchers can also print from their workstations and pay for the print outs, or else buy floppy discs from one of the information desks in the reading areas [25].

\subsection{Development of Library Collection}

As the main mission of the library is to be the window of Egypt on the world, and the window of the world on Egypt, and to be a library for the digital age. The library's cataloging and acquisition practices is strongly affected by this mission. Thus, the library collection varies between books available directly to be accessed for browsing and selecting (open stack-VOS), and books limited to the staff of the library or to a limited group of library users (closed stack-VCS). Also, other types of collection are available such as, a digital collection (DC), electronic books (EB), online databases (OD), printed scholarly journals (PSJ), daily newspapers (DN), electronic journals (EJ), theses (TS), specialized library's collection (SLC), and depository library collection (DLC). 
As Table 3 shows, the collection of Bibliotheca Alexandrina changed over time. For example, the volumes in open stacks was at its minimum value in 2003 with around 201 thousand book, and reached it maximum value in 2012 with about 288 thousand book, with an average estimated to be 240 thousand book added every year. The same goes for the volumes in closed stacks as its minimum value was in 2003 with around 19 thousand book, and reached its maximum value in 2012 with about 200 thousand book, having about 62 thousand book as an average annual addition. On the other hand, it seems that in the recent years, most of the volumes were added to the library collection as closed stacks as it suddenly jumped from 62 thousand book in 2010 to be around 152 thousand book in 2011, as Figure 7 shows.

In general, all of the other collection types such as the digital collection, electronic books, online databases, printed scholarly journals, daily newspapers, electronic journals, theses, specialized library's collection, and depository library collection has been increased over time but in different ranges.

\subsection{Development of Visitors and Membership}

The BA receives a numerous number of visitors annually, some of them are Egyptians while others are foreigners, and some of them individual visitors while others are guided tours, beside some of the visitors are VIPs, or even school students. Moreover, its websites receive more than two million hits every day. And it holds an average of around 700 cultural events every year.

Table 3. Collection development in BA, in thousands except for OD and DN.

\begin{tabular}{cccccccccccc}
\hline Year & VOS & VCS & DC & EB & OD & PSJ & DN & EJ & TS & SLC & DLC \\
\hline 2003 & 201.35 & 18.86 & 5.09 & 15.90 & 27.00 & 1.25 & 72.00 & 21.45 & 18.34 & 42.46 & 10.66 \\
2004 & 217.85 & 20.86 & 5.59 & 17.34 & 32.00 & 1.04 & 81.00 & 23.47 & 19.45 & 58.89 & 11.46 \\
2005 & 233.10 & 24.16 & 6.30 & 20.00 & 28.00 & 1.12 & 78.00 & 24.80 & 20.06 & 55.87 & 12.46 \\
2006 & 228.67 & 28.57 & 6.40 & 30.00 & 30.00 & 1.28 & 85.00 & 25.00 & 33.81 & 60.10 & 13.21 \\
2007 & 209.82 & 37.95 & 7.00 & 36.58 & 31.00 & 1.27 & 97.00 & 35.68 & 45.98 & 60.37 & 18.46 \\
2008 & 227.79 & 37.84 & 6.50 & 43.69 & 40.00 & 4.34 & 87.00 & 48.38 & 54.83 & 81.55 & 21.45 \\
2009 & 248.65 & 42.38 & 6.58 & 59.70 & 44.00 & 6.25 & 88.00 & 49.40 & 64.70 & 90.78 & 23.99 \\
2010 & 270.54 & 61.99 & 8.40 & 84.95 & 41.00 & 7.81 & 87.00 & 50.80 & 76.65 & 101.06 & 25.63 \\
2011 & 280.25 & 152.00 & 8.48 & 95.48 & 44.00 & 7.81 & 88.00 & 65.05 & 87.16 & 108.98 & 26.89 \\
2012 & 287.69 & 200.25 & 8.48 & 111.04 & 44.00 & 7.92 & 88.00 & 67.19 & 93.95 & 112.75 & 27.05 \\
\hline
\end{tabular}

Source: [26].

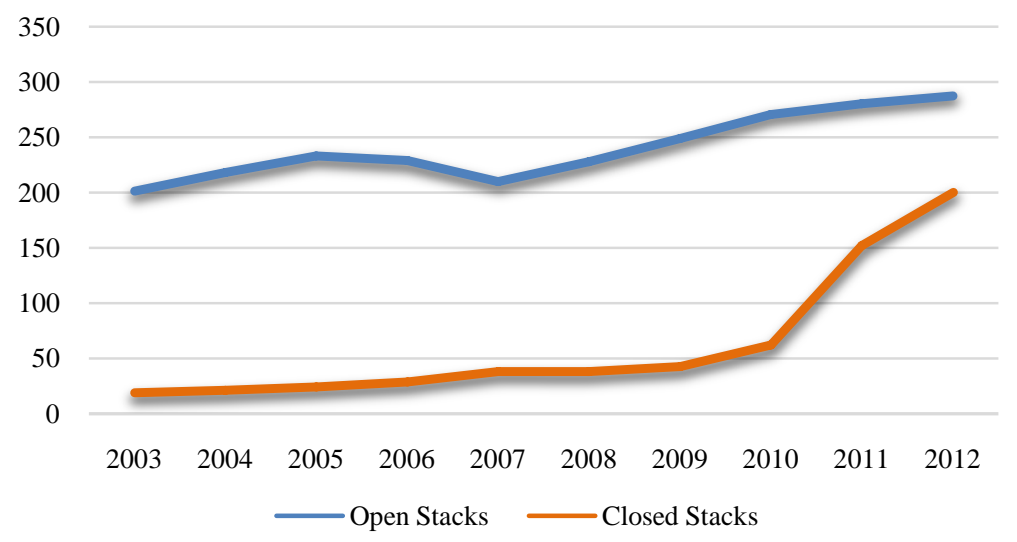

Figure 7. Development of open stack \& closed stack collection in BA. Source: [26]. 
As for the membership services, which provide a membership card that gives the benefit of using the library and all its facilities. borrow books, use reading areas, and reserve study rooms, if the member qualify. The Membership Card can also reduce rates to enter Museums, Exhibits and other Cultural Performances [25].

Number of visitors changes overtime, as it was at its minimum value in 2012 with about 107 thousand visitors, while it reached its maximum value in 2009 with about 320 thousand visitors. As for the membership, its minimum value estimated to be around 8 thousand members in 2003, and reached its maximum value in 2011 with about 18 thousand members, as Table 4 shows.

From Figure 8, it was clear the drop that occurred in the BA number of visitors from 227 thousand visitors in 2011 to reach about 107 thousand visitors in 2012, such behavior maybe explained as a result of the political events that happened in 2011 and the revolution which affected BA among other organizations \& facilities around the country.

\subsection{Staff and Library Management}

There are about 2000 staff members in BA, from 30 - 35 as an average, from both genders, and they are distributed between different categories such as senior and junior managers, security and service staff, consultants, and ordinary staff members.

Overall, the staff members tend to increase over time from 1639 members in 2006-originally was about 1200 members in 2003, to reach 2288 members in 2012, as Table 5 shows.

Table 4. Visitors and membership of BA.

\begin{tabular}{ccc}
\hline Year & Visitors & Membership \\
\hline 2003 & 231,921 & 8076 \\
2004 & 151,573 & 10,840 \\
2005 & 196,923 & 12,845 \\
2006 & 247,959 & 12,938 \\
2007 & 248,667 & 9835 \\
2008 & 317,174 & 11,396 \\
2009 & 319,500 & 15,438 \\
2010 & 310,000 & 15,898 \\
2011 & 227,000 & 17,638 \\
2012 & 106,800 & 16,322 \\
\hline
\end{tabular}

Source: [26].

Table 5. BA staff categories.

\begin{tabular}{|c|c|c|c|c|c|c|}
\hline Year & Sr. manager & Jr. manager & Staff & $\begin{array}{c}\text { Security \& } \\
\text { service staff }\end{array}$ & Consultants & Total \\
\hline 2006 & 43 & 120 & 832 & 613 & 31 & 1639 \\
\hline 2007 & 45 & 160 & 902 & 618 & 25 & 1750 \\
\hline 2008 & 45 & 156 & 1076 & 632 & 27 & 1936 \\
\hline 2009 & 47 & 168 & 1118 & 649 & 33 & 2015 \\
\hline 2010 & 66 & 207 & 1094 & 823 & 36 & 2226 \\
\hline 2011 & 68 & 250 & 1270 & 795 & 30 & 2413 \\
\hline 2012 & 48 & 223 & 1300 & 695 & 22 & 2288 \\
\hline
\end{tabular}

Source: [26]. 


\section{Results \& Discussion}

For the first step, results show that the relation between GDP and the allocated budget is linear relation as it is plotted in Figure 9.

Moreover, results show that Pearson's $\mathrm{r}$ is 0.96 which proves the existence of a strong relation between the country GDP and the government allocated budget to BA.

As for the second step, which testing the correlation between the allocated budget from one side, and (salaries \& wages, general \& administration expenses) from the other side. Results summarized in Table 6.

As the shows, there is a strong positive relation between the allocated budget and the salaries \& wages as Pearson's $r=0.96$, but on the other side, the relation between the allocated budget and the general expenses is insignificant. Which explains how library staff and librarians are very likely to be affected by any budget reallocation, which in turn affected by the economy GDP.

Lastly, results again shows a significant positive relation between the allocated budget and all of the other library indicators except for two of them, which are (the number of visitors, and the daily news), where they showed insignificant relation, as Figure 10 illustrates.

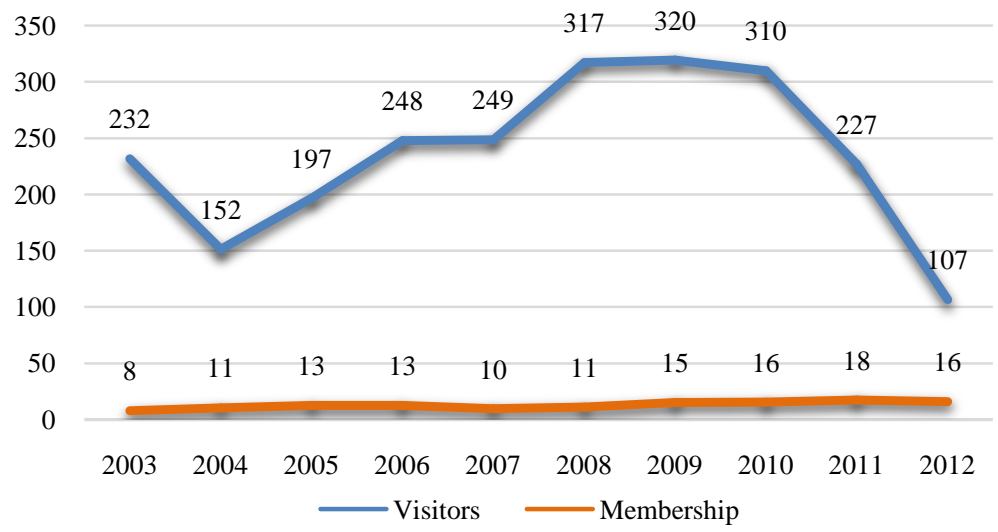

Figure 8. Number of visitors and members of BA. Source: [26].

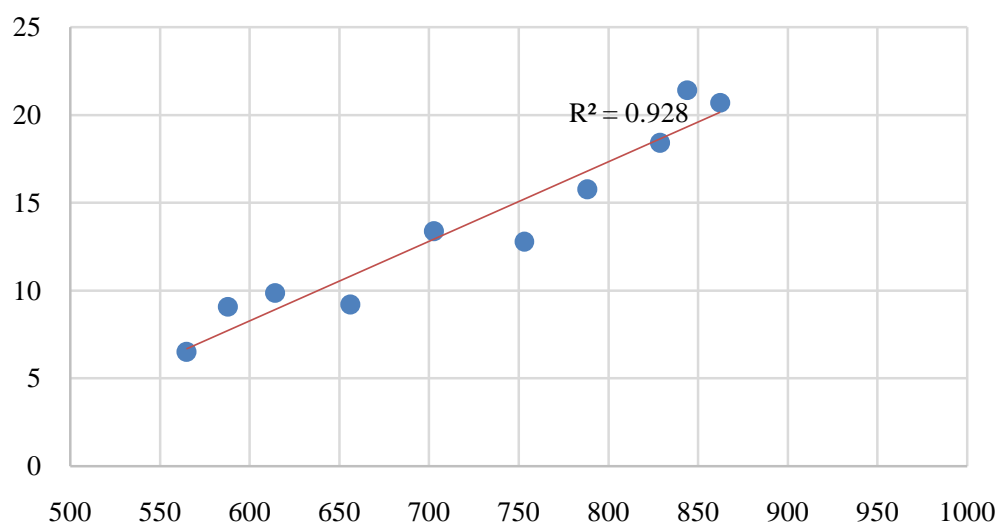

Figure 9. GDP \& allocated budget scatter plot.

Table 6. Pearson correlation results.

\begin{tabular}{cccc}
\hline Pearson correlation & Allocated budget & Salaries \& wages & General expenses \\
\hline Budget & 1 & $0.957^{* *}$ & 0.595 \\
Salaries \& wages & $0.957^{* *}$ & 1 & $0.748^{*}$ \\
General expenses & 0.595 & $0.748^{*}$ & 1 \\
\hline
\end{tabular}

${ }^{* *}$ Correlation is significant at the 0.01 level (2-tailed); ${ }^{*}$ Correlation is significant at the 0.05 level (2-tailed). 

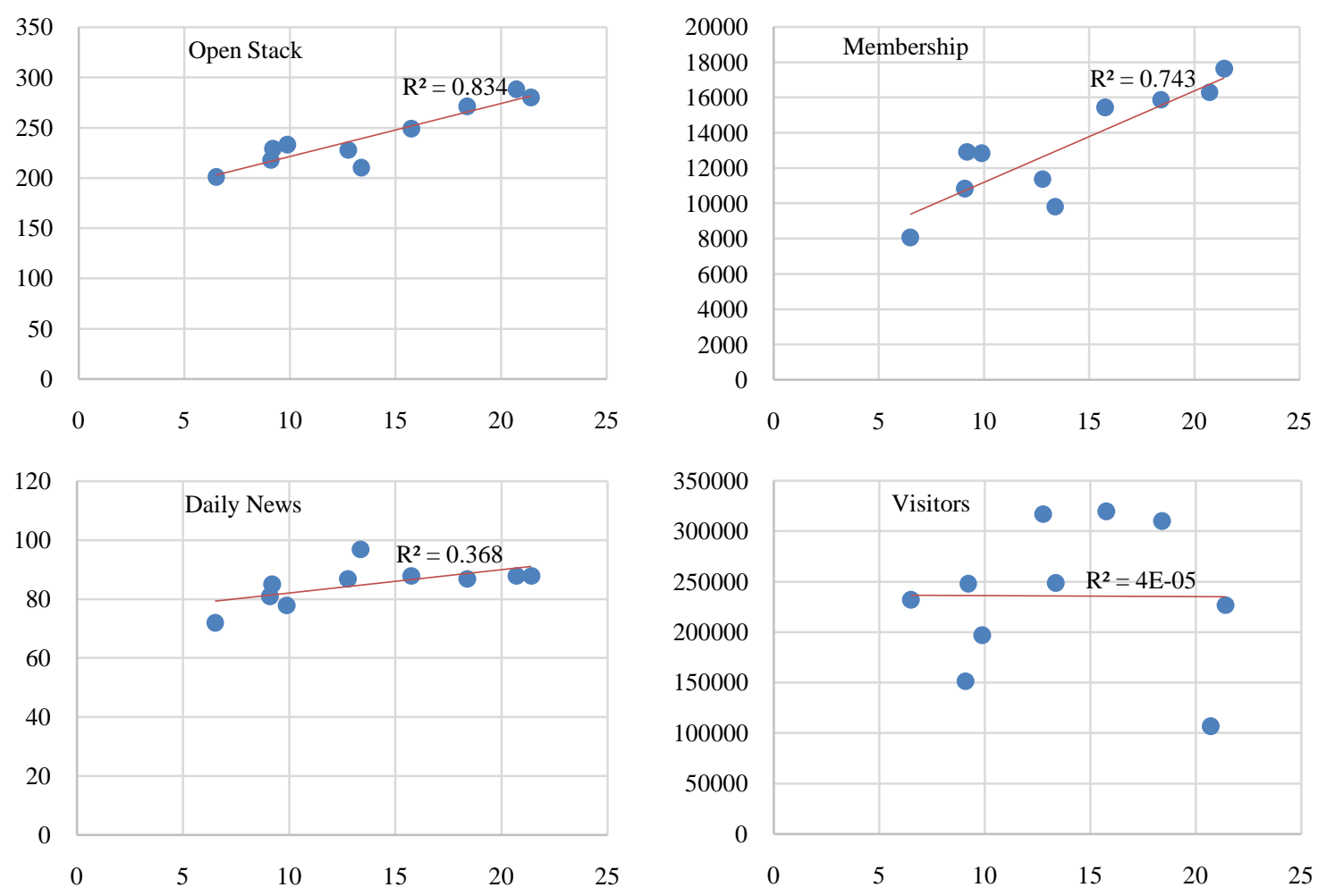

Figure 10. Pearson correlation results for some of the library indicators.

For example, Pearson's r equal 0.914 in the open stack books, which shows a strong relation between the allocated budget and this collection item. On the other hand, Pearson's $r$ is $(-0.006)$ in the visitors' analysis, which is insignificant.

\section{Conclusions}

Libraries such as Bibliotheca Alexandrina are a vital component in their local societies. The country economic development on the other hand could impact those components, and affects their ability to deliver sufficient services either directly or indirectly. To investigate this sort of impact, the research extracted data from the annual reports of Bibliotheca Alexandria about various library services, collections, and financial data. As for the data concerning the Egyptian economy, it has been extracted mainly from World Bank data.

Trying to prove such relationship, an analysis has been conducted over the data from 2003 until 2012. Using Pearson product-moment correlation coefficient, the analysis was conducted on two steps. The first one shows the relation between the country GDP and the library allocated budget. Then the second step takes place to investigate the correlation between the allocated budget and various library indicators.

Results show that Pearson's $r$ is 0.96 which proves the existence of a strong relation between the country GDP and the allocated budget. Then, for the second step results show that there is a strong positive relation between the allocated budget on one hand and the salaries \& wages on the other hand, which explains how library staff and librarians are very likely to be affected by any budget reallocation, which is in turn affected by the economy GDP.

Except for a number of visitors \& the daily news, most of the library indicators show a strong correlation with the allocated budget such as (open stack books, closed stack books, membership, etc.).

The descriptive analysis results also show that the government budget constitutes the bigger part of the library overall revenues, and other parts such as donations \& the library own investments and projects constantly decreased over time, which increase the dependence on the government allocated budget even more. Furthermore, if the library wants to achieve its own independency and decrease the government budget reallocation's risks, it should invest more in its own projects and investments. 


\section{References}

[1] UNESCO (2016) UNESCO Public Library Manifesto. [Online] http://www.unesco.org/webworld/libraries/manifestos/libraman.html

[2] Kamer, P.M. (2005) The Economic Value of the Northport-East Northport Public Library in Suffolk County. Long Island, New York.

[3] Indiana Business Research Center (2007) The Economic Impact of Libraries in Indiana. Indiana Business Research Center, Indiana.

[4] Glass, R.H., Clifford, N., Harris, B. and Rose, C. (2000) The Role of Public Libraries in Local Economic Development. The University of Kansas, Policy Research Institute, Kansas.

[5] Aabø, S. (2011) The Value of Public Libraries: A Socio-Economic Analysis. Editrice Bibliografica, 169-176.

[6] Santos, V.F.D. (2009) Public Libraries and Their Contribution towards Economic Development: A Discussion. Library and Information Science Research Electronic.

[7] Martin Prosperity Institute (2013) So Much More: The Economic Impact of the Toronto Public Library on the City of Toronto. Martin Prosperity Institute, Toronto.

[8] Barron, D.D., Williams, R.V., Bajjaly, S., Arns, J. and Wilson, S. (2005) The Economic Impact of Public Libraries on South Carolina. The School of Library and Information Science, University of South Carolina, South Carolina.

[9] The Urban Institute (2007) Making Cities Stronger: Public Library Contributions to Local Economic Development. Urban Libraries Council, Washington.

[10] Steffen, N., Lietzau, Z., Lance, K.C., Rybin, A. and Molliconi, C. (2009) Public Libraries—A Wise Investment: A Return on Investment Study of Colorado Libraries. Library Research Service.

[11] Stephen, A.R. (2003) Financial Management of Libraries: Past Trends and Future Prospects. Library Trends, $462-493$.

[12] Edward, A.W. (1963) Financial Support of Public Libraries. Library Trends, 343-352.

[13] Anne, M.-J. (2009) The Impact of Economic Recessions on Libraries: A Past, Present, and Future View From Minnesota. LIBREAS, Library Ideas.

[14] Balina, S. (2014) Public Libraries-Facilitators of Information Society and e-Inclusion in Latvia. Procedia-Social and Behavioral Sciences, 109, 412-416. http://dx.doi.org/10.1016/j.sbspro.2013.12.482

[15] Kate-Riin, K., Andres, K. and Signe, J. (2012) Financing of Estonian Research Libraries: The Happy Days and the Economic Crisis. Slavic \& East European Information Resources, 73-88.

[16] Denise, E.A. (2015) Alternative Funding for Public Libraries: Trends, Sources, and the Heated Arguments that Surround It. Influence of Funding on Advances in Librarianship, 31, 115-140.

[17] State Information Services (2016) Overview on the Modern History of Egyptian Economy. http://www.sis.gov.eg/En/Templates/Articles/tmpArticles.aspx?CatID=1353

[18] Trading Economics (2016) Egypt GDP Growth Rate. http://www.tradingeconomics.com/egypt/gdp-growth

[19] World DataBank (2016) World Development Indicators. http://databank.worldbank.org/data/reports.aspx?source=2\&country=EGY\&series=\&period=\#

[20] Bouri, E.N. (1994) Public Libraries Development Reconsidered: The Case of Egypt. International Information \& Library Review, 26, 151-168. http://dx.doi.org/10.1080/10572317.1994.10762336

[21] Smith, S.E. and Rasol, H.M. (2009) A Geographic Assessment of Public Libraries in Egypt. World Applied Sciences Journal, 6, 861-867.

[22] Central Agency for Public Mobilization and Statistics (2016) Public Services Statistics. http://www.capmas.gov.eg/Pages/IndicatorsPage.aspx?page id=6139\&ind id=1062

[23] Desouki, Y. (2007) The Bibliotheca Alexandria and the Preservation of Egypt's Visual Cultural Heritage. New York University, New York.

[24] Wikipedia (2015) Bibliotheca Alexandrina. https://en.wikipedia.org/wiki/Bibliotheca_Alexandrina

[25] Serageldin, I. (2002) Bibliotheca Alexandrina: The Rebirth of the Library of Alexandria. Bibliotheca Alexandrina, Alexandria.

[26] Bibliotheca Alexandrina (2003-2012) Annual Report-Various Versions. Bibliotheca Alexandrina, Alexandria.

[27] Bibliotheca Alexandrina (2012) Annual Report. Bibliotheca Alexandrina, Alexandria.

[28] Serageldin, I. (2006) Born Digital: The New Bibliotheca Alexandrina. Bibliotheca Alexandrina, Alexandria. 